\title{
Monitoring Keseimbangan Distribusi Beban Transformator untuk Meminimalisasi Terjadinya Rugi Energi
}

\author{
EDY SETIAWAN, GALIH ANINDITA, ACHMAD SYAHID, ISA RACHMAN \\ Politeknik Perkapalan Negeri Surabaya \\ Email:edy_setiawan@ppns.ac.id
}

Received 20 Desember 2018| Revised 6 Februari 2019| Accepted 24 Maret 2019

\begin{abstract}
ABSTRAK
Pola distribusi beban antara ketiga fasa pada saluran distribusi sekunder transformator kurang diperhatikan, berakibat ketidakseimbangan antara ke tiga fasa pada sistem distribusi sekunder transformator dan menyebabkan rugi energi yang terjadi pada jaringan distribusi sekunder akan semakin meningkat. Peneliti merancang sistem monitoring keseimbangan beban pada saluran distribusi sekunder transformator dengan metode eksperimen dan pembuatan prototipe. Penyimpangan rata-rata pembacaan sensor arus $6.7 \%$ dan pembacaan sensor tegangan $5.84 \%$ dan rugi energi terbesar didapatkan pada saat persen pembebanan di fasa $R=88,13 \%$, fasa $S=42,80 \%$ dan di fasa $T=20,14 \%$, yaitu 24,1 Wh pada penghantar netral dan 109,64 Wh pada penghantar pembumian.
\end{abstract}

Kata kunci: voltage sensing, current sensing, beban tidak seimbang, arus netral, rugi energi

\begin{abstract}
The pattern of load distribution between the three phases in the transformer secondary distribution channel is not noticed. This situation results in an imbalance between the three phases of the transformer secondary distribution and causes energy losses that occur in the secondary distribution network will increase. The researcher designed a load balance monitoring system in the transformer secondary distribution channel with the experimental method and prototype manufacturing. The average error of the current sensing at $6.7 \%$, for the voltage sensing interface is $5.84 \%$ and the biggest energy loss is obtained at $\%$ loading on phase $R=88,13 \%$, phase $S=42,80 \%$ and phase $T=20.14 \%$, system reading 24,1 Wh on neutral conductor and 109,64 Wh on earthing conductor.
\end{abstract}

Keywords: voltage sensing, current sensing, unbalanced load, neutral current, energy loss 


\section{PENDAHULUAN}

Setiap perusahaan memiliki standar mutu untuk setiap produk yang dihasilkan. Tidak terkecuali PLN sebagai perusahaan yang menghasilkan produk berupa energi listrik. Beberapa standar mutu produk ini kemudian ditetapkan dalam putusan Direksi PT. PLN No. 109.K/039/DIR/1997 tentang Penggunaan Piranti Tenaga Listrik (PLN, 2013). Sedangkan tegangan tidak seimbang adalah adanya perbedaan tegangan terhadap referensi pada salah satu atau semua fasa. Penyebab ketidakseimbangan tegangan salah satunya adalah distribusi beban tidak seimbang pada setiap fasa, dan pendistribusian beban yang tidak seimbang ini juga dapat menyebabkan rugi energi terutama pada jaringan distribusi sekunder tegangan rendah pada pemanfaatan energi listrik (PLN, 2013). Ketidakseimbangan penyebaran beban pada jaringan distribusi 3 fasa dapat di-monitoring melalui rugi daya atau rugi energi yang terjadi akibat adanya arus yang mengalir pada netral transformator (Kawihing, 2013). Rugi daya yang terjadi pada jaringan distribusi sekunder akan semakin meningkat seiring dengan semakin besarnya arus yang mengalir pada netral transformator. Indikator ini menunjukkan distribusi beban pada setiap fasanya tidak sama. Kerugian yang terjadi akibat beban yang tidak seimbang akan berdampak besar pada pihak konsumen maupun pihak PLN. Satu sumber menunjukkan $62 \%$ daya yang dihasilkan hilang dalam pembangkitan dan $2 \%$ hilang dalam transmisi dan distribusi (Kenneth, 2011). Annual Energy Review (AER) tahun 2010 dari U.S Energy Information Administration (EIA) melaporkan $65,8 \%$ energi terbuang dalam kerugian pembangkitan, transmisi dan distribusi. Sehingga kira-kira dua pertiga daya hilang dalam pembangkitan, transmisi dan distribusi. Peningkatan efisiensi energi trafo low-voltage, pada sisi distribusi akan mengurangi beban pada kapasitas pembangkit listrik kira-kira tiga kali energi penghematan (Kenneth, 2011).

\section{METODOLOGI}

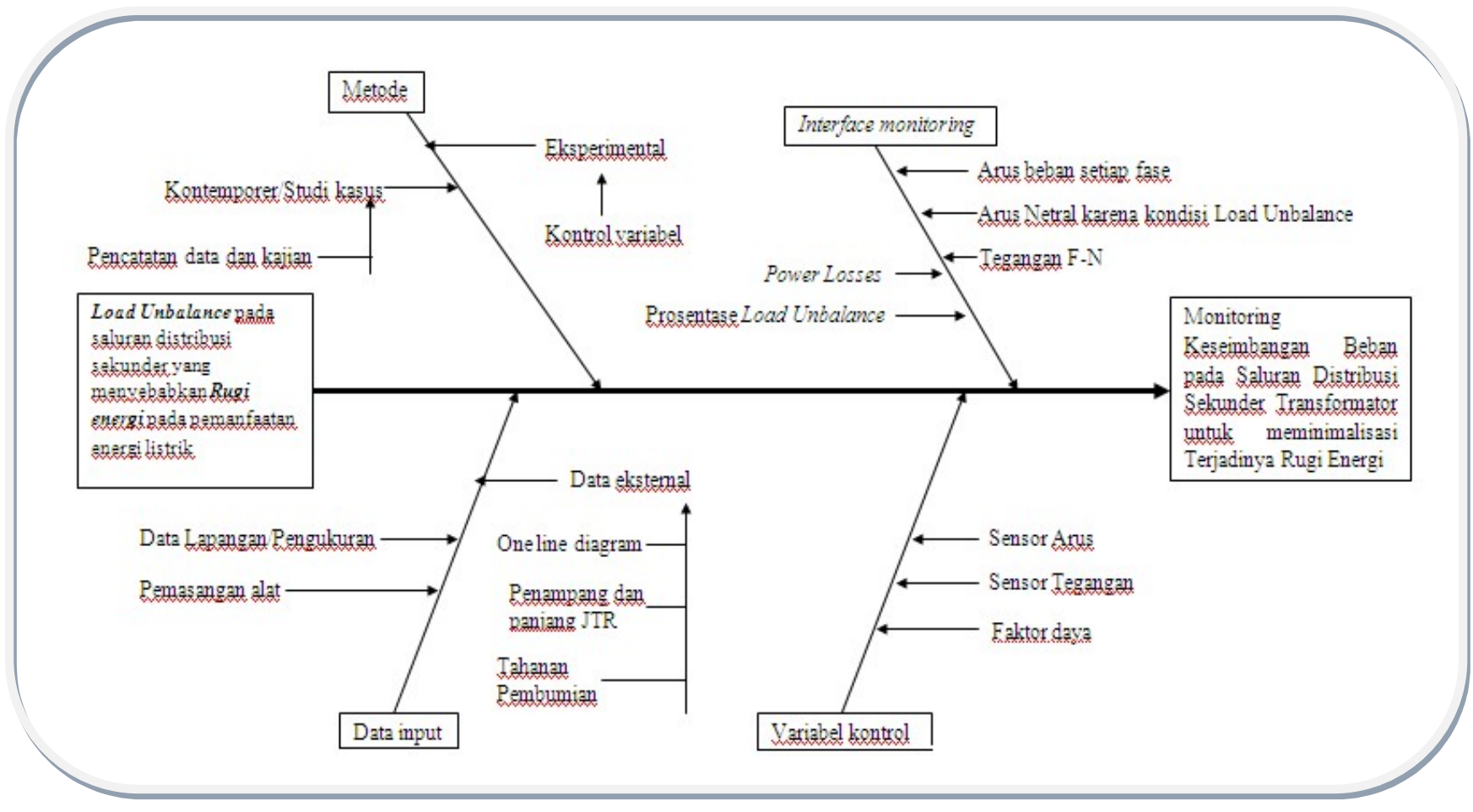

Gambar 1. Fishbone Diagram 
Metode yang digunakan dalam pengukuran ini adalah eksperimental, merekam data dengan seksama, menghubungkan satu sama lain untuk menganalisis, dan melakukan proses pengukuran sesuai fishbone diagram pada Gambar 1. Metode eksperimen yang dilakukan dengan membuat sebuah prototipe dengan variasi beban berbeda kemudian memasang sensor arus (SCT-013-000) dan sensor tegangan (AC adapter) pada setiap fasa dan membandingkan dengan hasil analisis dan perhitungan. Berkenaan dengan pengukuran rugi daya dan energi perlu memperhatikan juga data eksternal berupa luas penampang, panjang JTR dan besarnya tahanan pembumian. Alat ukur standar yang digunakan dalam pengukuran menggunakan oscilloscope GW GOS-622G 20MHz INSTECT, AC/DC clamp meter KEW SNAP Model 2003A, FLUKE 117 True RMS Multimeter dan Lutron wattmeter.

\section{HASIL DAN ANALISIS}

\subsection{Diagram Sistem}

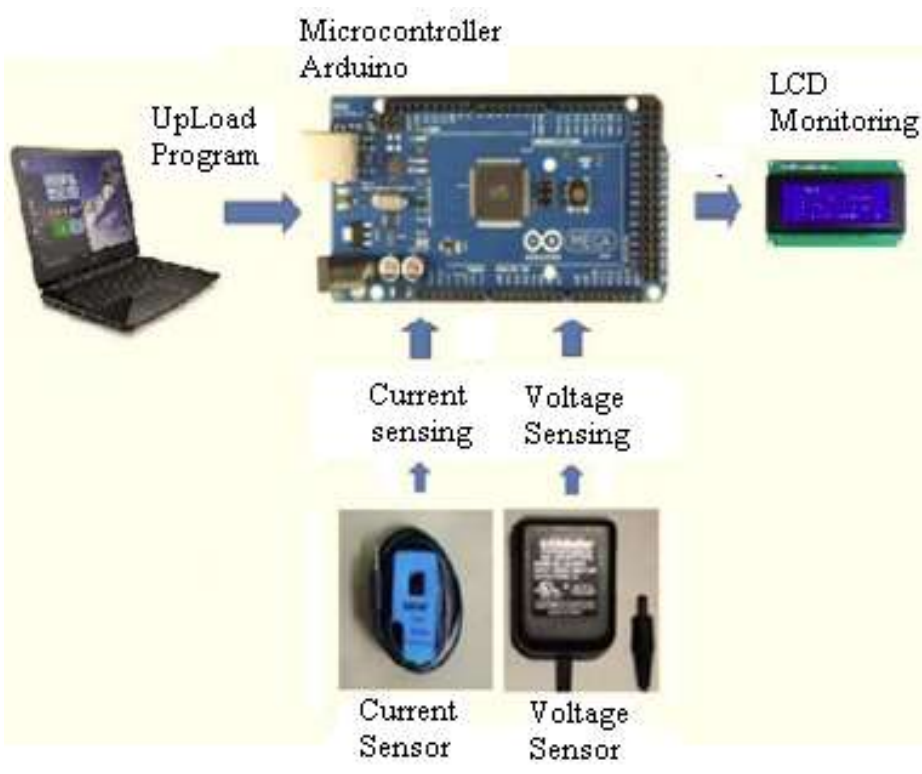

Gambar 2. Diagram Sistem Monitoring

Berdasar Gambar 2, diagram sistem tersebut tersusun beberapa komponen hardware sebagai berikut, sensor SCT-013-000 (0 100A/0 50mA), sensor tegangan berupa AC adapter 0 240 VAC/9 VAC, current sensing, voltage sensing, LCD monitoring dan mikrokontroler Arduino yang merupakan embeded sistem yang terdiri dari, CPU, RAM, ROM, I/O Port, Timer, ADC dan peripheral lainnya (Mazidi, 2008)(Banzi, 2008). Instrumen yang digunakan untuk mengukur jumlah listrik dalam utilitas, seperti voltmeter, amperemeter dan wattmeter, disebut sebagai instrumen switchboard. Sangat sering sistem instrumentasi adalah bagian dari sistem kontrol proses. Sistem pengukuran dalam penelitian ini melibatkan listrik analog (tegangan, arus, daya dan faktor daya). Rancangan pengukuran yang dibuat pada sistem ditunjukkan pada Gambar 3. Sensor tegangan akan menurunkan tegangan sistem daya ke nilai kompatibel dengan sistem elektronik digital dan analog. Dalam hal ini, sensor tegangan digunakan untuk menurunkan tegangan ke $9 \mathrm{~V}$ peak-to-peak. Arus harus diukur dalam garis fasa tunggal yang memasok $240 \mathrm{~V}$. Pilih amperemeter dan trafo arus (sensor) yang sesuai (Beaty, 2001). 


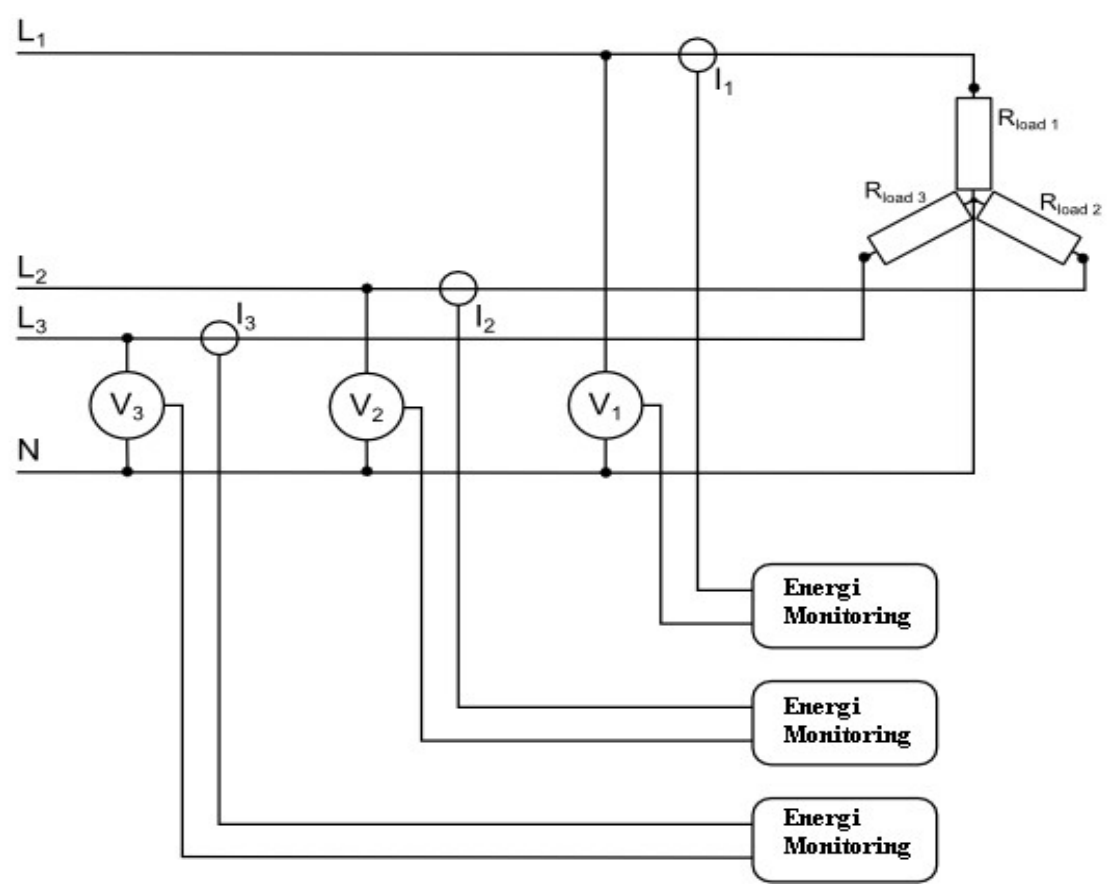

Gambar 3. Desain Pengukuran pada Monitoring Energi

Untuk rangkaian interface antara sensor arus dengan Arduino dapat dijelaskan berdasarkan Gambar 4 berikut ini (Setiawan, 2018).

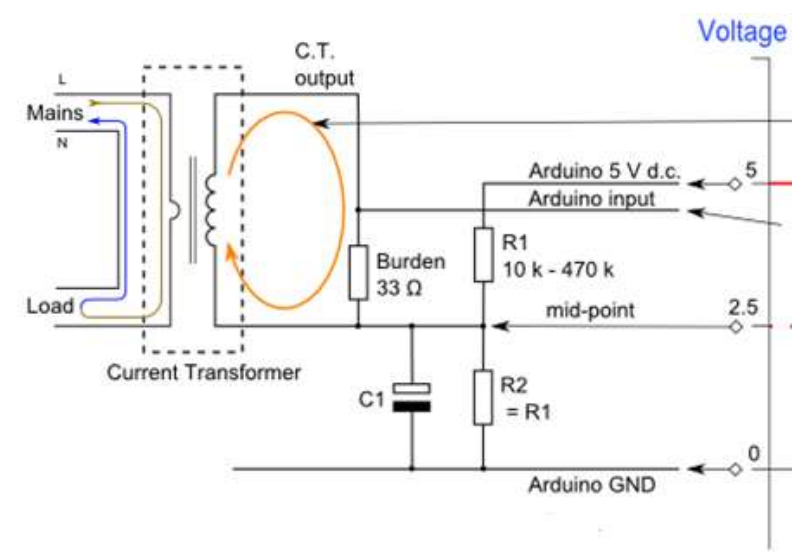

\section{Gambar 4. Rangkaian Interface antara Sensor Arus (Current Sensing) dengan Arduino}

YHDC SCT-013-000 CT mempunyai range masukan 0 100 Ampere (Robert, 2014).

Primary peak - current $=$ RMS current $\times \sqrt{2}$

$$
\begin{aligned}
& =100 \mathrm{~A} \times 1.414 \\
& =141.4 \mathrm{~A}
\end{aligned}
$$

YHDC SCT-013-000 CT mempunyai 2000 turns (Wuidart, 1999), jadi secondary peak current dapat dihitung sebagai berikut:

$$
\begin{aligned}
\text { Secondary peak }- \text { current } & =\frac{\text { Primary peak-current }}{2000} \\
& =\frac{141.4 \mathrm{~A}}{2000} \\
& =0.0707 \mathrm{~A}
\end{aligned}
$$


Jika menggunakan Arduino, nilai tegangan yang digunakan adalah $5 \mathrm{~V}$. Untuk menentukan nilai beban $R$ yang ideal menggunakan perhitungan (AREF/2)/secondary peak-current, dengan nilai AREF adalah 5 volt.

Jadi beban $\mathrm{R}$ yang ideal yang terpasang pada rangkaian Gambar 4 adalah:

$$
\begin{aligned}
\text { Ideal burden resistance } & =\frac{\frac{\text { AREF }}{2}}{\text { Secondary peak-curren }} \\
& =\frac{2.5 \mathrm{~V}}{0.0707 \mathrm{~A}} \\
& =35.4 \Omega
\end{aligned}
$$

rekomendasi burden resistance (resistor beban) $33 \Omega \pm 1 \%$. (penyesuaian nilai yang ada di pasaran)

Untuk rangkaian interface sensor tegangan dengan Arduino dapat dijelaskan berdasarkan Gambar 5 berikut ini (Setiawan, 2018).

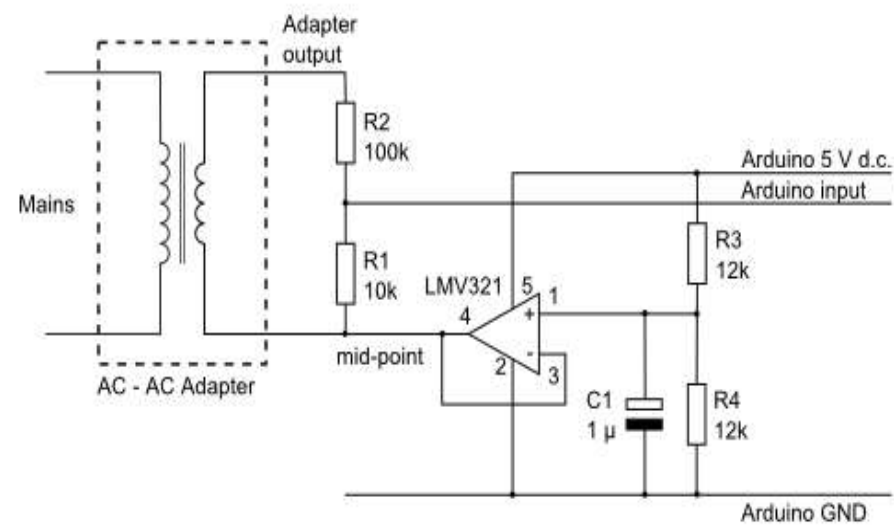

\section{Gambar 5. Rangkaian Interface antara Sensor Tegangan (Voltage Sensing) dengan Arduino}

Tegangan $9 \mathrm{~V}$ (RMS) adaptor output, memberikan tegangan puncak positif $12.7 \mathrm{~V}$, negatif -12.7 V. Resistor R1 dan R2 membentuk pembagi tegangan yang skala bawah tegangan AC power adapter. Resistor R3 dan R4 memberikan tegangan bias. Kapasitor C1 menyediakan jalur impedansi rendah ke tanah untuk sinyal AC. Nilai C1 tidak terlalu diperhatikan, antara 1 uF dan 10 uF telah cukup. R1 dan R2 perlu dipilih untuk memberikan puncak-teganganoutput. Untuk adaptor AC-AC dengan output $9 \mathrm{~V}$ (RMS), kombinasi resistor $10 \mathrm{k} \Omega$ untuk R1 dan $100 \mathrm{k} \Omega$ untuk R2 :

$$
\begin{aligned}
\text { Peak_Voltage_Output } & =\frac{R 1}{(R 1+R 2)} \times \text { Peak_Voltage_Input } \\
& =\frac{10 K \Omega}{(10 K \Omega+100 K \Omega)} \times 12.7 \mathrm{~V} \\
& =1.15 \mathrm{~V}
\end{aligned}
$$

Jika Arduino berjalan pada $5 \mathrm{~V}$, bentuk gelombang yang dihasilkan memiliki puncak positif dari $2.5 \mathrm{~V}+1.15 \mathrm{~V}=3.65 \mathrm{~V}$ dan puncak negatif $1.35 \mathrm{~V}$ telah cukup untuk Arduino, memenuhi analog persyaratan tegangan input. 


\subsection{Hasil Pengujian Sistem}

\subsubsection{Pengujian Sensor Arus dengan Interface Current Sensing}

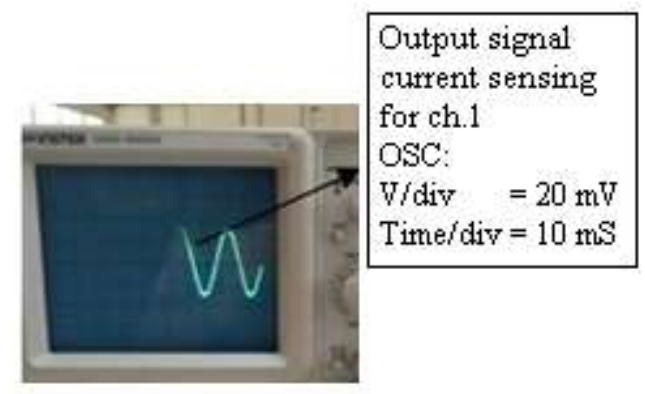

Gambar 6. Hasil Pengujian Sensor Arus dengan Interface Current Sensing Beban 300 W

Beban pada saat pengujian 300 watt, arus yang terbaca dengan menggunakan instrumen ukur standar sebesar 1.2 A. Maka,

$$
\begin{aligned}
\text { Primary peak-current } & =\text { RMS current } \times \sqrt{2} \\
& =1.2 \mathrm{~A} \times 1.414 \\
& =1.697 \mathrm{~A}
\end{aligned}
$$

$$
\begin{aligned}
\text { Secondary peak-current } & =\frac{\text { Primary peak-current }}{2000} \\
& =\frac{1.697 \mathrm{~A}}{2000} \\
& =0.848 \mathrm{~mA}
\end{aligned}
$$

Sehingga, tegangan keluaran pada $\mathrm{R}=33 \Omega$ adalah:

$$
\begin{aligned}
V(33 \Omega) & =33 \Omega \times 0.848 \mathrm{~mA} \\
& =0.02799 \mathrm{~V} \\
& =27.99 \mathrm{mV}(\text { Tegangan puncak })
\end{aligned}
$$

Maka,

$$
V p p=27.99 \mathrm{mV} \times 2=55.98 \mathrm{mV}
$$

Hasil perhitungan di atas jika dibandingkan dengan hasil pengukuran, seperti yang ditunjukkan pada Gambar 6 menggunakan instrumen standar OSC GW GOS-622G 20 MHz INSTECT, terlihat ada penyimpangan, secara keseluruhan hasil pengujian dan analisis perhitungan ditunjukkan pada Tabel 1.

Tabel 1. Hasil Pengujian Sensor Arus dengan Interface Current Sensing dalam Besaran Tegangan

\begin{tabular}{|c|c|c|c|c|}
\hline $\begin{array}{c}\text { Beban } \\
(\mathbf{W})\end{array}$ & $\begin{array}{c}\text { Pengukuran } \\
\mathbf{( m V})\end{array}$ & $\begin{array}{c}\text { Perhitungan } \\
\mathbf{( m V )}\end{array}$ & $\begin{array}{c}\text { Penyimpangan } \\
\mathbf{( m \mathbf { m } )}\end{array}$ & $\begin{array}{c}\text { Penyimpangan } \\
(\mathbf{\%})\end{array}$ \\
\hline 100 & 8 & 6,99 & 1,01 & 12,6 \\
\hline 200 & 20 & 18,67 & 1,33 & 6,65 \\
\hline 300 & 30 & 27,99 & 2,01 & 6,7 \\
\hline 400 & 42 & 39,66 & 2.34 & 5.57 \\
\hline 500 & 48 & 46,66 & 1.34 & 2.79 \\
\hline 600 & 60 & 55,99 & 4.01 & 6.68 \\
\hline
\end{tabular}




\begin{tabular}{l|l|l} 
Rata-rata penyimpangan & 2,00 & 6,83
\end{tabular}

\subsubsection{Pengujian Sensor Tegangan dengan Interface Voltage Sensing}

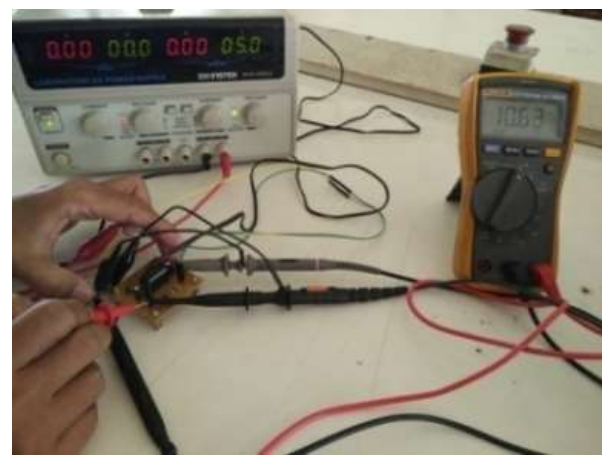

Gambar 7. Hasil Pengujian Tegangan Keluaran Sensor AC-AC Adapter 1 Fasa

Hasil pengukuran output sensor tegangan (AC adapter) seperti yang ditunjukkan pada Gambar 7, terukur $V_{\text {rms }}$ sebesar 10.6 V. Sehingga didapatkan tegangan puncak sebagai masukan pada voltage sensing sebagai berikut :

$$
\begin{aligned}
\text { Peak_voltage_input } & =V r m s \times \sqrt{2} \\
& =10.6 \times 1.414 \\
& =14.99 \mathrm{~V}
\end{aligned}
$$

Dengan hukum pembagi tegangan sesuai dengan rangkaian yang dibuat, maka:

$$
\begin{aligned}
\text { Peak_voltage_output } & =\frac{R 1}{R 1+R 2} \times \text { Peak_voltage_input } \\
& =\frac{10 \mathrm{~K} \Omega}{10 \mathrm{~K} \Omega+100 \mathrm{~K} \Omega} 14.99 \\
& =1.37 \mathrm{~V}
\end{aligned}
$$

Sehingga,

Peak to peak voltage output $=2 \times 1.37 \mathrm{~V}=2.74 \mathrm{~V}$

Tabel 2. Hasil Pengujian Keluaran Sensor AC-AC Adapter 1 Fasa

\begin{tabular}{|c|c|c|c|}
\hline $\begin{array}{c}\text { Pengukuran } \\
(\mathbf{V})\end{array}$ & $\begin{array}{c}\text { Perhitungan } \\
(\mathbf{V})\end{array}$ & $\begin{array}{c}\text { Penyimpangan } \\
(\mathbf{V})\end{array}$ & $\begin{array}{c}\text { Penyimpangan } \\
(\%)\end{array}$ \\
\hline 15,02 & 14,98 & 0,4 & 2,4 \\
\hline 14,5 & 14,8 & 0,3 & 2,0 \\
\hline 14,0 & 13,8 & 0,2 & 1,4 \\
\hline 12,5 & 13,0 & 0,5 & 3,8 \\
\hline 12,0 & 12,3 & 0,3 & 2,4 \\
\hline 11,5 & 11,6 & 0,1 & 0,9 \\
\hline 11,0 & 10,8 & 0,2 & 1,9 \\
\hline 10,0 & 10,0 & 0 & 0 \\
\hline 9,0 & 9,4 & 0,4 & 4,3 \\
\hline 8,0 & 8,2 & 0,2 & 2,4 \\
\hline \multicolumn{4}{|l}{ Rata-rata penyimpangan } \\
\hline
\end{tabular}




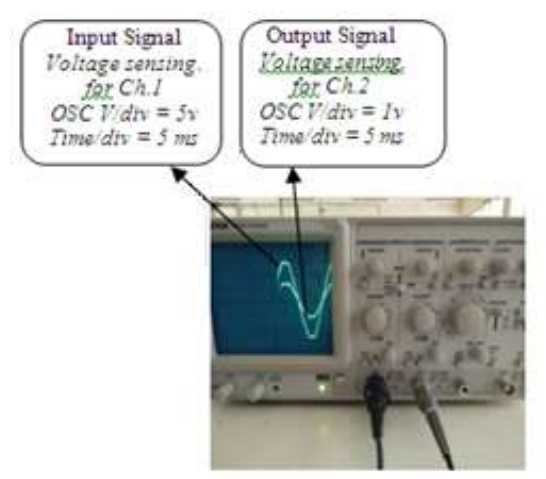

Gambar 8. Hasil Pengujian Sensor Tegangan dengan Interface Voltage Sensing

Tabel 3. Hasil Pengujian Keluaran dari Interface Voltage Sensing

\begin{tabular}{|c|c|c|c|}
\hline $\begin{array}{c}\text { Pengukuran } \\
(\mathbf{V})\end{array}$ & $\begin{array}{c}\text { Perhitungan } \\
(\mathbf{V})\end{array}$ & $\begin{array}{c}\text { Penyimpangan } \\
(\mathbf{V})\end{array}$ & $\begin{array}{c}\text { Penyimpangan } \\
(\%)\end{array}$ \\
\hline 1,26 & 1,47 & 0.21 & 14.28 \\
\hline 1,20 & 1,30 & 0.1 & 7.69 \\
\hline 1,15 & 1,20 & 0.05 & 4.16 \\
\hline 1,08 & 1,17 & 0.09 & 7.69 \\
\hline 1,0 & 1,11 & 0.11 & 9.90 \\
\hline 0,89 & 1,04 & 0.15 & 14.42 \\
\hline 0,80 & 0,97 & 0.17 & 17.52 \\
\hline 0,75 & 0,9 & 0.15 & 16.66 \\
\hline 0,68 & 0,84 & 0.16 & 19.04 \\
\hline 0,61 & 0,74 & 0.13 & 17.56 \\
\hline \multicolumn{3}{|r}{ Rata-rata penyimpangan } \\
\hline
\end{tabular}

\subsubsection{Pengujian Sistem Keseluruhan}

Pengujian dilakukan untuk mengetahui keberhasilan sistem yang telah dibuat baik secara hardware maupun software. Hasil pengujian ditunjukkan pada Tabel 4, dengan memberikan variasi nilai pada regulator tegangan dan melakukan pembandingan antara pembacaan alat ukur standar dengan pembacaan sensor, penyimpangan rata-rata yang dihasilkan sebesar 5.84\%. Tabel 5, merupakan hasil pengujian untuk pembacaan sensor arus,dengan mengatur variasi nilai beban dan melakukan pembandingan antara pembacaan alat ukur standar dengan pembacaan sensor,penyimpangan rata-rata yang dihasilkan sebesar $6.7 \%$.

Tabel 4. Hasil Pengujian untuk Pembacaan Sensor Tegangan

\begin{tabular}{|c|c|c|c|c|}
\hline $\begin{array}{c}\text { Tegangan } \\
\text { referensi } \\
(\mathbf{V})\end{array}$ & $\begin{array}{c}\text { Pembacaan } \\
\text { instrumen standar } \\
(\mathbf{V})\end{array}$ & $\begin{array}{c}\text { Pembacaan } \\
\text { sensor } \\
(\mathbf{V})\end{array}$ & $\begin{array}{c}\text { Penyimpangan } \\
(\mathbf{V})\end{array}$ & $\begin{array}{c}\text { Penyimpangan } \\
(\%)\end{array}$ \\
\hline 10 & 10.7 & 13 & 2.3 & 21.5 \\
\hline 20 & 21.5 & 23.32 & 1.82 & 8.47 \\
\hline 30 & 30.5 & 33.87 & 3.37 & 11.05 \\
\hline 50 & 50.2 & 52.57 & 2.37 & 4.72 \\
\hline 75 & 75 & 76.92 & 1.92 & 2.56 \\
\hline 100 & 100 & 103.17 & 3.17 & 3.17 \\
\hline 125 & 125.3 & 128.30 & 3.27 & 2.60 \\
\hline 150 & 150.5 & 154.39 & 3.89 & 2.58 \\
\hline 200 & 200.2 & 203.73 & 3.53 & 1.76 \\
\hline 220 & 222.2 & 226.7 & 4.5 & 2.02 \\
\hline \multicolumn{4}{|r}{ Rata-rata Penyimpangan } \\
\hline
\end{tabular}


Tabel 5. Hasil Pengujian untuk Pembacaan Sensor Arus

\begin{tabular}{|c|c|c|c|c|}
\hline $\begin{array}{c}\text { Beban } \\
(\mathbf{W})\end{array}$ & $\begin{array}{c}\text { Pembacaan } \\
\text { instrumen standar } \\
(\mathbf{A})\end{array}$ & $\begin{array}{c}\text { Pembacaan } \\
\text { sensor } \\
(\mathbf{A})\end{array}$ & $\begin{array}{c}\text { Penyimpangan } \\
(\mathbf{A})\end{array}$ & $\begin{array}{c}\text { Penyimpangan } \\
(\mathbf{\%})\end{array}$ \\
\hline 200 & 0.80 & 0.87 & 0.07 & 8.75 \\
\hline 300 & 1.20 & 1.28 & 0.08 & 6.67 \\
\hline 400 & 1.70 & 1.74 & 0.04 & 2.35 \\
\hline 500 & 2.0 & 2.16 & 0.16 & 8.0 \\
\hline 600 & 2.40 & 2.59 & 0.19 & 7.91 \\
\hline \multicolumn{4}{|c}{ Rata-rata Penyimpangan } \\
\hline
\end{tabular}

Pada pengujian saluran distribusi sekunder trafo tiga fasa,data yang akan dibaca oleh sistem dalam penelitian ini adalah IR (rms), IS (rms), IT (rms) dan Vfasa-line (rms). Data beban trafo diberikan berdasarkan Tabel 6.

Tabel 6. Distribusi Beban Transformator 3 Fasa

\begin{tabular}{|c|c|c|c|c|}
\hline \multicolumn{3}{|c|}{$\begin{array}{c}\text { Arus } \\
\text { (A) }\end{array}$} & \multicolumn{2}{c|}{$\begin{array}{c}\text { Tegangan } \\
\text { (V) }\end{array}$} \\
\hline R & S & T & Fasa-fasa & Fasa-line \\
\hline 1.2 & 1.7 & 2.4 & 385 & 235 \\
\hline 2.4 & 1.2 & 1.7 & 385 & 235 \\
\hline 3.5 & 1.7 & 0.8 & 385 & 235 \\
\hline 2 & 2.4 & 0.8 & 385 & 235 \\
\hline 2.4 & 1.7 & 0.8 & 385 & 235 \\
\hline
\end{tabular}

Diberikan data existing sebagai berikut :

- Penghantar netral

$$
\begin{aligned}
& L=650 \mathrm{~m} \\
& A=500 \mathrm{~mm}^{2}=0.0005 \\
& \rho=0.0175
\end{aligned}
$$

- Tahanan grounding

$$
\mathrm{R}=5 \Omega
$$

- Power/phase: 2.8 kVA/3 Phase

- Cos phi $=0.85$

Persentase pembebanan pada transformator dihitung dengan menggunakan Persamaan (9) dan Persamaan (10).

$\% k V A=\frac{k V A_{\_} \text {terukur }}{k V A_{-} \text {terpasang }} \times 100 \%$

$k V A_{\text {terukur }}=\frac{\text { fasa }_{\text {line }} \times(I R+I s+I}{1000}$

Persentase pembebanan pada transformator untuk setiap fasa dihitung dengan menggunakan Persamaan (11) dan Persamaan (12). 
$\% k V A=\frac{\left(k V A_{-} \text {fasa_terukur }\right)}{\frac{k V A_{-} \text {terpasang }}{3}} \times 100 \%$

$k V A_{-} f a s a \_t e r u k u r=\frac{\left(V f a s a \_l i n e\right) \times(I f a s a)}{1000}$

Perhitungan besarnya arus netral yang disebabkan ketidakseimbangan beban dihitung berdasar Persamaan (13), (14) dan Persamaan (15).

$$
\begin{aligned}
& I N=I R \angle 0^{\circ}+I S \angle 120^{\circ}+I T \angle 240^{\circ} \\
& I N=I R\left(\operatorname{Cos} 0^{\circ}+J \operatorname{Sin} 0^{\circ}\right)+I S\left(\operatorname{Cos} 120^{\circ}+J \operatorname{Sin} 120^{\circ}\right)+I T\left(\operatorname{Cos} 240^{\circ}+J \operatorname{Sin} 240^{\circ}\right) \\
& I N=\sqrt{(\text { Real })^{2}-(\text { Imaginer })^{2}}
\end{aligned}
$$

Secara keseluruhan hasil pengujian ketidakseimbangan beban ditunjukkan pada Tabel 7

\begin{tabular}{|c|c|c|c|c|c|}
\hline \multicolumn{3}{|c|}{$\%$ Beban tiap fasa } & \multirow[b]{2}{*}{$\begin{array}{l}\mathbf{I}_{\mathbf{N}} \\
(\mathbf{A})\end{array}$} & \multirow[b]{2}{*}{$\begin{array}{l}\text { Rugi energi pada } \\
\text { penghantar netral } \\
\text { (WH) }\end{array}$} & \multirow{2}{*}{$\begin{array}{c}\text { Rugi energi pada } \\
\text { penghantar } \\
\text { pembumian } \\
\text { (WH) }\end{array}$} \\
\hline Phasa R & Phasa S & Phasa T & & & \\
\hline 30.21 & 42.80 & 60.43 & 1.04 & 4.63 & 21.08 \\
\hline 60.43 & 30.21 & 42.80 & 1.04 & 4.63 & 21.08 \\
\hline 88.13 & 42.80 & 20.14 & 2.38 & 24.10 & 109.64 \\
\hline 50.36 & 60.43 & 20.14 & 1.44 & 8.84 & 40.22 \\
\hline 60.43 & 42.80 & 20.14 & 1.39 & 8.20 & 37.32 \\
\hline
\end{tabular}
berikut ini.

Tabel 7. Hasil Pengujian Pembebanan pada Transformator 3 Fasa

Hasil pembacaan sistem yang ditunjukkan pada Tabel 7 diatas, terkait persentase pembebanan pada fasa $R$, fasa $S$, fasa $T$ dan juga rugi energi yang timbul pada penghantar netral maupun pada penghantar grounding karena kondisi ketidakseimbangan beban akan ditampilkan pada layar LCD 16x2. Setiap ada perubahan pembebanan, sistem akan memperbarui tampilan pada layar LCD. Hasil penelitian ini merupakan pengembangan penelitian yang pernah dilakukan sebelumnya (Kawihing, 2013) memilki kelemahan pada saat akan melakukan penyambungan beban pada setiap fasa harus terlebih dahulu dilakukan pengukuran, analisis dan perhitungan secara berulang-ulang untuk mendapatkan pemerataan beban pada setiap fasanya.

\section{KESIMPULAN}

Berdasarkan hasil pengujian sistem monitoring keseimbangan beban pada saluran distribusi sekunder transformator untuk meminimalisasi terjadinya rugi energi akibat adanya arus netral, penyimpangan rata-rata rangkaian antarmuka pembacaan sensor arus $6.7 \%$, pembacaan sensor tegangan $5.84 \%$ dan rugi energi terbesar didapatkan pada saat persen pembebanan di fasa $R=88,13 \%$, fasa $S=42,80 \%$ dan di fasa $T=20,14 \%$, yaitu $24,10 \mathrm{Wh}$ pada penghantar netral dan 109,64 Wh pada penghantar pembumian. 


\section{UCAPAN TERIMA KASIH}

Kami tidak lupa mengucapkan banyak terima kasih kepada Ristek Dikti, Politeknik Perkapalan Negeri Surabaya dan juga rekan dosen yang telah sharing pengetahuan, memberikan dukungan sehingga dapat terselesaikan penelitian ini dengan baik.

\section{DAFTAR RUJUKAN}

Banzi, M. (2008). Gettting Started with Arduino, First Edition. Canada: O'Reilly Media, Inc.

Beaty, H. W. (2001). Handbook of Electric Power Calculations, Third Edition. New York: McGraw-Hill.

Kawihing, A.I. dkk. (2013). Pemerataan Beban Transformator pada Saluran Distribusi Sekunder. e-jurnal Teknik Elektro dan Komputer, 2(1), 1-9.

Kenneth, D.H. (2011). Optimizing Energy Effeciency Standarts for Low Voltage Distribution Transformers. Indiana: Purdue University Fort Wayne.

Mazidi, M.A., Mazidi, J.G., Mckinlay, R.D. (2008). The 8051 Microcontroller and Embedded Systems Using Assembly and C, Second Edition. India: Pearson Education.

PLN. (2013). Mutu Produk Menuju World Class Services 2015, Edisi 2. Jawa Timur: PT.PLN Distribusi Jawa Timur.

Robert, W. (2014). A Report on the properties of the Yhdc Current Transformer and its suitability for use with the Open energy monitor.

Setiawan, E., Anindita, G., Syahid, A., Rachman, I. (2018). Implementation of Signal Defects Caused by The Effect of Harmonics on The Use of Electricity Loads. Manado: ICAST 2018.

Setiawan, E., Anindita, G.,Syahid, A., Rachman, I. (2018). Penerapan Filter Aktif sebagai Cara Menaikkan Nilai Faktor Daya pada Penggunaan Beban Nonlinier. Surabaya: MASTER 2018.

Wuidart, L. (1999). Understanding Power Factor. Italy: STMicroelectronics. 